\title{
Kentli Bireylerin Kırsal Mekân Algısı ve Kırsal Mekân Tüketimi: Antalya-Çakırlar Örneği
}

\section{Rural Space Perception \& Rural Space Consumption of Urban Individuals: Antalya-Çakirlar Case}

\section{Arzu AÇAR* Murat ATALAY ${ }^{* *}$}

Öz: Alan yazınında kentli bireylerin kırsal mekân tüketimine yönelik araştırmaların sayı bakımından az olduğu dikkat çekmektedir. Günümüzde kentli bireylerin kentlerdeki yapay mekânlar dışında kırsal mekânları tüketme eğilimi göstermesi konuyu araştırmaya değer bir duruma getirmektedir. Bu bağlamda araştırmanın amacı kentli bireylerin kırsal mekân ve kırsal mekân tüketimiyle ilgili algılamalarını anlamak ve açıklamaktır. Bunun için kentli bireylerin kırsal mekân tüketimine yönelik algılarını anlamaya yönelik nitel bir araştırma tasarlanmıştır. Bir metropol olan Antalya kentine yakın mesafede bulunan Çakırlar kırsal bölgesi araştırma için seçilmiştir. Bu kırsal mekânı tüketen bireyler ve mekân sahipleri ile görüşmeler yapılmıştır. Yapılan görüşmeler sonucunda kırsal mekânı tüketen kentli bireylerin kırsal mekânı ve kırsal mekân tüketimini nasıl algıladıklarına yönelik temalar belirlenmiştir. Araştırma sonucunda doğallık ve sağlık, samimiyet, nostalji ve otantiklik, kentten uzaklaşma ve sosyal ortama katılım olarak 5 ana tema ortaya çıkmıştır.

Anahtar sözcükler: Mekân tüketimi, Kırsal mekân, Kentli birey, Antalya-Çakırlar

Abstract: That there have been only a few studies that have exclusively examined the rural space consumption of urban individuals is remarkable. Nowadays urban individuals' tendency of consuming rural spaces which are outside artificial urban spaces makes this topic worth examining. In this context, the purpose of this study is to explain and understand the perceptions of urban individuals regarding rural space and rural space consumption. A qualitative study is designed in order to understand the urban individuals' perceptions of rural space consumption. In line with the purpose of the study the Çakırlar rural area, in close proximity to Antalya metropolitan city was selected. Interviews were conducted with the consumers and the owners of this rural space. As a result of the interviews specific themes have been identified regarding how urban individuals perceive the rural space and rural space consumption. As a result of the study five main themes have emerged which have been termed: naturalness and health, intimacy, nostalgia and authenticity, getting away from the city and participation in social ambiance.

Keywords: Space consumption, Rural Space, Urban individuals, Antalya-Çakırlar

\section{Giriş}

$\mathrm{Bu}$ çalışmanın konusunu, kentlerde yaşayan bireylerin kırsal mekân algıları ve kırsal mekân

\footnotetext{
* PhD., Akdeniz Üniversitesi, Sosyal Bilimler Enstitüsü, İşletme ABD., Antalya, arzuacar985@gmail.com

* Arş. Gör., Akdeniz Üniversitesi, Sosyal Bilimler Enstitüsü, İşletme ABD., Antalya, atalay@akdeniz.edu.tr Bu çalışma, Doç. Dr. Gönül DEMEZ’in 2013-2014 eğitim-öğretim yılı güz dönemi Kültürel Çalışmalar adlı doktora dersi kapsamında yürütülmüştür.
} 
tüketimindeki eğilimleri oluşturmaktadır. Bireylerin tükettiği mekânların çeşitliliği ve mekânları tüketme amaçları gündelik yaşamın önemli bir parçası olması nedeniyle bu çalışmanın odağını oluşturmaktadır. Kentlerde yaşayan bireylerin çok sayıda alışveriş merkezi, kapalı siteler, plazalar arasında "steril" yaşamlar sürdürdükleri ve kentli bireylerin gündelik yaşamlarının büyük bölümünü bu “yapay” mekânlarda geçirdikleri gözlemlenmektedir.

Kentler kalabalık, farklı tabakalardan bireyleri barındıran, mekânlarda insan müdahalesinin fazla olduğu yerlerdir. Alan yazınında kentli bireylerin tükettikleri alışveriş merkezleri, eğlence merkezleri, kültür merkezleri, kapalı siteler gibi mekânlar gündelik yaşama yönelik araştırmalara sıkça konu olmaktadır. Kentli bireyler bu kalabalık yerde ve "yapay" mekânlar içinde farklı bireylerle bir araya gelmekte ancak "sosyalleşme" açısından sorunlar yaşayabilmektedir. Giddens, kasaba ve kentlerde yaşayan insanların büyük çoğunluğunun kişisel olarak tanımadıkları başka insanlarla sürekli olarak etkileşim içine girdiklerini ve en karmaşık toplumlarda bile başka insanların varlığının yaşamsal olduğunu belirtmektedir (Giddens, 2000, 74). Kentlerdeki kalabalıklar başka insanların varlığına duyulan ihtiyacı gidermekte ancak başka insanlarla etkileşim ve ilişki kurma eksikliğinin hissedildiği gözlemlenmektedir.

Kentli bireyler tükettikleri mekânları kente özgü mekânlar dışında çeşitlendirebilmektedir. Kentli bireylerin "boş zaman" ya da "tatil günü” geçirmek için tükettikleri mekânlar kente özgü olanlar kadar, kırsal, doğal, şehir dışı mesire yerleri gibi mekânlardan da oluşabilmektedir. Kentlere özgü mekânlardan farklı olarak, bireylerin kırsal mekânları tüketmeye eğilim göstermelerinin dikkat çekici olduğu düşünülmektedir.

$\mathrm{Bu}$ araştırma, alan yazınında konuyla ilgili varsayımlardan yola çıkarak, araştırmanın konusuna ve amacına uygun bir kırsal mekân olan Çakırlar bölgesinde gerçekleştirilmiştir. Son 15-20 y1lda Antalya kenti içerisinde yaşayan kentli bireylerin günübirlik vakit geçirmek için Çakırlar bölgesini tercih ettikleri gözlemlenmektedir. Çakırlar, bir metropol olan Antalya kentinde (Garipağaoğlu, 2010, 25) günübirlik vakit geçirilebilecek yakınlıkta (yaklaşık $11 \mathrm{~km}$ ) yer alan kırsal mekân özelliği göstermektedir. Özellikle son yıllarda bu kırsal mekâna olan yoğun talep araştırmacıların dikkatini çekmiştir. Bu nedenle mekânın, kentli bireylerin günlük yaşamda kırsal mekân tüketimine yönelik bir araştırma için uygun olacağı düşünülmüştür. Antalya kentine yakın bir kırsal mekân olan Çakırlar bölgesini tüketen kentli bireyler ve buradaki mekânların sahipleri araştırmanın hedef kitlesini oluşturmaktadır. Bu araştırmada nitel araştırma deseni kullanılmış ve temelde mekânı tüketen kentli bireylerin algılamaları araştırılmıştır. Bu bağlamda araştırma sorusu kentli bireylerin kırsal mekânı ve kırsal mekân tüketimini nasıl algıladıklarıdır.

$\mathrm{Bu}$ araştırmanın kentli bireylerin kırsal mekânları neden ve nasıl tükettiklerinin daha iyi anlaşılmasına katkı sağlayacağı düşünülmektedir. Özellikle uluslararası alan yazınında bu konudaki çalışmaların sayı bakımından oldukça az olması bu araştırmanın önemini artırmaktadır. Ulusal alan yazınında ise çoğunlukla kentli bireylerin kentsel mekânlarla (Örneğin AVM'ler, rezidanslar, plazalar, kafeler) ilgili tercihleri ve algılamaları araştırılmış, kırsal mekân tercih ve algılamalarına neredeyse hiç yer verilmemiştir. Bu nedenle çalışmanın amacı kentli bireylerin kırsal mekân ve kırsal mekân tüketimiyle ilgili algılamalarını anlamak ve açıklamak ayrıca alan yazınında bu konuyla ilgili boşluğun doldurulmak istenmesidir.

Çalışmada öncelikle kentlerdeki gündelik yaşamda tüketim ve mekân tüketiminin kavramsal temeline, sonrasında bireylerin kırsal mekân tüketimi ile ilgili alan yazınındaki görüşlere değinilecektir. Daha sonra kırsal mekân tüketimi algısı ve eğilimine yönelik bireyler ve mekân sahipleri üzerine yapılan nitel araştırmaya yer verilecektir. Son olarak ise bulgular tartışılacak, araştırmanın kısıtlarından bahsedilecek ve gelecekte yapılacak araştırmalar için öneriler geliştirilecektir. 


\section{Gündelik Yaşamda Kent, Mekân ve Mekân Tüketimi}

1920'lerde kentleşme fikrini ortaya atan Wirth'e göre, kentler binlerce insanı barındıran büyük yerlerdir. Kentteki insanlar her zaman hareket halindedir ve bir şeyler satın almak veya bir işi halletmek için şehirde bulunurlar. Kazanç peşinde koştukları için hoşça vakit geçirmeye ayıracak zamanları yoktur. Kentler bireylerin mücadele ve rekabet ettiği bir keşmekeştir (Slattery, 2010, 286). Büyük bir kent yabancıların dünyasıdır; ancak yabancılarla kişisel ilişkileri destekler ve yaratır. Kentlerde yaşayanlar çok fazla hareketli olma eğiliminde olduklarından aralarındaki bağlar göreli olarak zayıftır. Her gün birçok farklı etkinlik ve durum içinde yer alırlar, yaşamın hızı kırsal kesimlerden daha hızlıdır. Rekabet işbirliğinin önünde gider (Giddens, 2000, 507-508).

Birçok sosyal bilim alanında olduğu gibi sosyoloji için de kent, kentte gelişen sosyo-kültürel ve ekonomik ilişkiler temel ilgi alanıdır. Weber, Durkheim, Simmel gibi sosyologlar çeşitli yönlerden kenti ve kentsel yaşamı toplumsal dönüşümün niteliğini kavramak amaciyla incelemişlerdir. Mekân sorunsalını Weber, kapitalist topluma geçişin temelinde yatan rasyonelleşme, Durkheim ise toplumsal dayanışma ve modern dinamiklerin toplumsal birliktelik üzerine etkileri olarak ele almıştır. Foucault, mekân tartışmalarına yönelik olarak hızlı kentleşme sonucu ortaya çıkan asayiş sorununu ele almıştır. Certeau, gündelik yaşamın çözümlenmesinde mekânın önemli konumuna işaret etmekte ve mekân kavramını toplumsal bir inşa olarak görmektedir. Lefebvre ise toplumsal mekânın hem geçmiş eylemlerin ürünü olduğunu hem de gelecek faaliyetlerin oluşmasına olanak sağladığını belirtmektedir. Mekân hem eylem alanı hem de eylemin temelini oluşturandır (Işı1k, 2009, 13-21). Weber'e göre kent bir pazar alanıdır. Kent birbirinden ayrı evlerden ve mahallelerden oluşmuş kapalı bir yaşam alanı olduğu için oturanlar birbirlerini tanımazlar (Turkan, 2012, 85-104).

Genel perspektiften bakıldığında, yaşanılan kenti/çevreyi anlamak için mekânsal yapıları ve buralarda cereyan eden sosyal/kültürel süreçleri kavramak önem taşımaktadır. Kentler, sosyal süreçlerle mekânsal yapıların sürekli bir etkileşim içinde olduğu organik yapılardır (Aytaç, 2007, 201). Kent, kolektif tüketime en hızlı ve kolay erişimi sağlayan mekânlar ve bu mekânların dayattığı yaşam biçimleri demektir. Aynı zamanda iş bölümünün getirdiği kurumsallaşma ile zamanda ve mekânda bölünme anlamına gelmektedir (Altan, 2008, 13).

Günümüz kentleri, farkl1 siyasetlerin bulunduğu, mekân, insan, zaman, kimlik, kültür, imge ve göstergelerin kaotik olarak bir arada bulunduğu, oldukça heterojen ve kozmopolit alanlardır. Üzerinde yaşayan insanlar için yer/mekân olmanın ötesinde toplumsal/politik aidiyetlere, farklı yaşam deneyimlerine, kimliksel ve kültürel çoğulculuğa, yeni bakış ve düşünsel formlara karş1lık gelirler. $\mathrm{Bu}$ yönleriyle, toplumsal gruplaşmalar, kültürel çeşitlilik, çoklu kimlikler, farklı sosyaliteler ve yaşam stillerinin köken bulduğu verimli bir havzadırlar (Aytaç, 2007, 202). Bir kent ne kadar fazla kurumsallaşırsa o derece büyümektedir. 'Metropol' günümüzde bu büyümeyi küresel başlık altında niteleyen bir kavramdır. Her şeyden önce para ekonomisinin egemenliği altında uzmanlaşmış bir yapıyı ifade eder: "Metropol, yeni kültür teknolojileri açısından örgütlü, küresel pazarın bir uzantısı olarak artık çok geniş bir anlam taşımaktadır" (Williams, 1992, Akt. Altan, 2008, 7).

Kentsel mekânlar, birer gündelik hayat mekânıdırlar. Gündelik hayatın geçtiği mekânlar, özellikle de kamusal mekânlar, beden, dil, söylem, temsil vs. gibi imgesel ögeler üzerinden birer mikro mücadele alanını oluşturur. Goffman (1959), Sennett $(1996,1999)$ ve Lefebvre'in (1991, 1998) çözümlemelerinde bunu açık bir şekilde görürüz (Aytaç, 2007, 212). Kent olgusu her şeyden önce toplumbilimsel bir sorun çıkarır karşımıza. Kent ve insan, günümüzün kurumsallaşmış yaşam biçimleri bağlamında düşünüldüğünde; birbirlerinin bağımlılıkları içinde varlık 
kazanirlar (Altan, 2008, 6).

Sanayileşme ile birlikte kent insanı da kır insanı da zaman ve mekânı eski yaşama biçiminden çok farklı biçimde yaşamaya başlamıştır. Milyonlarca insan doğduğu yerde yaşam sürmek yerine okumak, işe girmek, terfi etmek için durmadan mekân değiştirmek zorunda kalmıştır. Bu durum sürekli ve köklü beşeri ilişkileri zorlaştırmış, insanların yalnızlık içinde yaşamasına neden olmuştur. İnsanlar arası ilişkiler bakımından ise kentler, sahip olunan statüler sayesinde insanların önemsendiği, kişiliklerin hesaba katılmadığı, akrabalık ve arkadaşlı̆̆ın sınırlandığı, bakmadan yaşanan mekânlara dönüşmüştür (Aydoğan, 2009, 212).

Kentlerdeki bireylerin ortak mekân kullanımı giderek azalmakta, kent dokusunun belleği anlamına gelen meydanlar yok olmaktadır. Etkileşimi olanaklı kılan kolektif dayanışma davranışlarının yerini 'yalnızlık duygusu' almaktadır. Bu bağlamda metropol sakininin belirgin özelikleri şu şekilde sıralanabilir: Can sıkıntısı, güvensizlik, eylemsizlik, tatminsizlik, huzursuzluk, nedensiz öfke, duyarsızlık, bağımlılık, amaçsızlık, aykırılık, içtensizlik, aşırı haz düşkünlüğü vb. (Altan, 2008, 13-15).

İnsan-doğa ilişkisinin dönüşümü insanın doğaya hükmetme eylemi üzerine kurulmuş olmasına rağmen, günümüzde doğa "şehir sinırları içine sıkıştırılmış" bir şekilde konumlandırılmaktadır. Bu açıdan değerlendirildiğinde postmodern insan kentleşme ve getirisi birçok olumsuz etkenle başa çıkmak ve şehir gerçekliğinden kaçmak için doğaya yönelme yolunu seçmektedir. Birey görmüştür ki doğayla olan mesafesi arttıkça doğa kendisine yabancılaşmakta, merkezsiz bir mutluluk arayışı içerisine girmektedir. Bir yandan doğayı sonuna kadar sömüren bir anlayış güdülürken diğer yandan doğa, kentin sıkışmışlığında özlenen, kutsanan ve başka bir şeyle yeri doldurulamayan özel bir konumdadır. Bunun ayırdına varan pazarlama stratejileri bireylere " $\operatorname{dog} a$ " vurgulu söylemlerle seslenmekte, yeni teknolojiler ise doğayla özdeş bireyin klasik özlemlerini kullanmaya odaklanmaktadır. Böylece toplumda tüketim alışkanlıkları doğainsan ilişkisinin bu dönüşümü üzerinden kurulmakta, bu dönüşüm tüketim kültürünün devamlılığında en önemli unsurlardan biri olarak karşımıza çıkmaktadır (Uğurlu, \& Tire, 2011).

Kent, kent yaşamı, kentli bireyler konusuna yukarıda değindikten sonra, mekân tüketimi konusu ele alınacaktır. Ancak önce sosyolojik açıdan "tüketim" ve "boş zaman" konusuna değinmenin uygun olacağ d düşünülmüştür. Bütün toplumlar her zaman zorunlu harcamalar ötesinde har vurup harman savurmuş, harcamış ve tüketmiştir. Günlük yaşam yalnızca günlük olayların ve hareketlerin toplamı, sıradanlığın ve yinelemenin boyutu değil bir yorumlama sistemidir ve tüketimin yeri günlük yaşamdır (Baudrillard, 2008, 28). Bir toplumda tüketim ile toplumsal tabakalaşma arasındaki ilişkiye ilk defa dikkati çeken Veblen, tüketimin amacının hiçbir zaman sadece biyolojik ihtiyaçların tatmini olmadığını belirtmektedir. Her toplumda tüketim, tüketicinin toplumsal statüsünü göstermek gibi biyolojik ihtiyaçlarla aynı derecede önemli diğer bir fonksiyona sahiptir (Kıray, 2005, 17-18).

Sosyologlara göre tüketim birçok gündelik özelliğin bir arada bulunması doğrultusunda gerçekleşir. Bu özellikler kullanım, keyif ve anlamdır. Bu şekilde toplum tarafından özel anlamlar atfedilen, "işaretlenen", anlamı kuvvetlendirilen ürünlerin tüketimi bireyin toplumdaki yerini sağlamlaştırıp, kişiliğini bir sosyal zümreye oturttuğu gibi toplumsallaşmasına da katkı sağlamaktadır. Bu mekânları ya da malları tüketme isteği sadece bir ihtiyaçtan değil, o malların ve mekânların bize verdiği hazdan kaynaklanmaktadır (Turkan, 2012, 93). Bir kişinin tüketimi sadece gelirine değil, birlikte yaşadığ 1 , iletişim kurduğu kişilerin tüketim şekillerine de bağlıdır. Onlarla karşıllıklı ilişki halindedir. Duesenberry tüketim kuramında bu duruma "gösteriş etkisi" demektedir. Duesenberry bireyin tüketimini toplumsal bir faktörün tayin ettiğini ileri sürmektedir (Kıray, 2005, 20). 
Kentli bireylerin tüketim alışkanlıkları sadece mal ve hizmetlerle sınırlı olmamakta, mekânlarda vakit geçirmek aracılığıyla mekânlar da tüketilmektedir. Mekânlarda vakit geçirme bağlamında boş zaman (leisure) kavramına değinmek gerekmektedir. Boş zaman, büyük ölçüde işin gerekliliği ve zorlayıcılığından kurtulma, özgürleşme anlamı taşır. İradi yönelmeler ve tercihleri kapsayan bir serbest olma zamanı/yaşamı olarak tanımlanır. Özgürleşmeden denetime kadar bir dizi anlamı içerir. Özellikle de, seçme/tercih, kaçış, spontanelik ve özgürlük anlamlarıyla yakından ilişkilidir. İş'in zorlayıcı dünyasından, gevşeme, ferahlama ve de kendini sal1verme durumuna bir nevi kaçışı ifade eder (Hibbins, 1996, 23, akt. Aytaç, 2006, 28). İstirahat, kafa dinleme, eğlence belki bir ihtiyaçtır ama kendiliğinden zaman tüketiminin kendine özgü talebini tanımlamazlar. Boş zaman onu doldurmak için yapılan tüm oyuncul etkinliklerdir, ama öncelikle zamanı kaybetme özgürlüğüdür. Zamanın gerçek kullanım değeri boş zaman etkinliklerinin umutsuzca yeniden oluşturmaya çalıştığı şey kaybedilmektir (Baudrillard, 2008, 198).

Farklı alanlar, kasabalar, tarımsal bölgeler, yeni ticaret alanları, alışveriş merkezleri, ana ulaşım yolları gibi mekânlar sadece belirli bir mekânsal yapının öğeleri ve insan etkinliğinin dışarıdan belirleyicileri değillerdir. Bunlar toplumsaldır, bulundukları toplumdan ve karşılıklı bağlı oldukları karakteristik biçimlerden ayrılamazlar. Mekânsal olanın toplumsal olandan ayrılamamasının sebebi mekânın tek başına genel etkiler taşımamasıdır (Urry, 1999, 97). Mekân tüketimine yönelik çalışmalar yapan Urry, mekânın içine yerleşen maddi nesnelerden ayrı görülmemesi gerektiğini ve mekânın sadece bu tür nesnelere de indirgenemeyeceğini belirtmektedir (1999, 96). Bu bağlamda bireyler mekânlar yoluyla, hayata tutunur, aidiyet, bağlanma, kimlik, özdeşlik ilişkisi kurarlar. Kimi zaman zevk almak, eğlenmek, sosyal aidiyet kurmak için kimi zamanda yaşamsal zorluklardan kaçmak adına bu mekânlarda bulunurlar. Bir yaşam tarzına karş11ık geldikleri gibi, aynı zamanda, kentteki özgürlüğü, serbestiyi, başına buyruk hareket etme keyfiyetini de müdavimlerine sunarlar (Aytaç, 2007, 203).

Kent mekânları derken, kentli bireylerin gündelik yaşamlarını sürdürmelerine aracılık eden, kentin ve kentliliğin inşasında aracı rol üstlenen minör kurumlar akla gelmektedir. Bu kurumlar, kentin politik/iktisadi coğrafyası dışında yer alan, daha açık bir şekilde kentin kültürel yüzeyini yansıtan mekânlardır. Örneğin, sinemalar, tiyatrolar, restoranlar, pastaneler, müzeler, galeriler, kütüphaneler, oteller, barlar, birahaneler, kafeler, kahvehaneler, parklar vs. kentin gündelik yaşamının üzerine inşa edildiği yerler olarak modern yaşamın odak kurumları arasında yer almaktadırlar (Aytaç, 2007, 200-203).

Turkan’a (2012, 93) göre mekân tüketimi her bireyin sosyal hayatı boyunca fark etmeden yaptığı ve sık sık tekrarladığı bir harekettir. Mekânların seçimi ilk olarak ekonomik duruma bağlı olsa da diğer yandan sosyal ve kültürel durum ile ihtiyaç, zevk ve alışkanlıklarımız doğrultusunda da farklılık göstermektedir. Kentteki her bir mekân/yer, işlevleri, kültürel iklimi, iç mekân kurgusu, müdavimlerin sosyal, statüsel, kültürel temsili itibariyle benzeşik öğelere sahip oldukları gibi ayırıcı/ayrıştırıcı bir niteliğe de sahiptirler. Kentteki değişik türden mekânlar, ötekilerin karşılaşması, kendilerini göstermelerine aracılık etmeleri itibariyle, farklı kültürelliklerin karşılaşmasına, iç içe geçmesine ve yeni ya da melez kültürel biçimlerin kök salmasına alan açar (Aytaç, 2007, 220).

Kente ait olandan farklı olanı tüketme isteği ve arayışı kentli bireyleri farklı mekân tüketimine yönlendirdiği gözlemlenmektedir. Bunlardan göze çarpanı "kırsal”, "yöresel”, “doğa” gibi kavramlarla tanımlanan mekânları tüketmektir. Kentli bireyin kırsal mekân tüketimine bir sonraki başlıkta yer verilecektir ancak modern yaşamın "doğal" ve "kırsal” olanı kendine ait bir şekilde yeniden yaratıyor/üretiyor olması dikkat çekmektedir. Özünel (2011, 255-262) turizme yönelik çalışmasında, turizmin hareketlendiği yıllardan itibaren sistemli bir biçimde imha edilen 
yöresel olanın yerini "yöreselmiş gibi" olana bıraktığını belirtmiş ve bunu bir örnekle açıklamıştır. Sahil kentlerinin plastik ve bambu sandalyeli "gözleme çadırları" ve restoranları, safari adı altında deve üzerinde gerçekleştirilen sözde yöresel turlar, hediyelik eşya tezgâhlarını süsleyen Çin malı "yöresel ve otantik" eşyalar bu çerçevede ele alınabilir. Zamanla üretilen bu yapay otantiklik ve yöresellik algısı herkesçe içselleştirilmiş ve bu kavramlar kimlik algımızın inşasında da başat rol oynamışlardır (Özünel, 2011, 259).

\section{Kentli Bireylerin Kırsal Mekân Tüketimi}

Kontrolsüz ve hızlı bir şekilde gerçekleşen kentleşme ve sanayileşme süreci ile birlikte gerçekleşen doğa tahribatı, fiziksel koşullardaki bozulma, kentsel mekânlarda insanların maruz kaldıkları baskılar, ulaşım problemleri ve çevre sorunları insan hayatını tehdit eder duruma gelmiştir. $\mathrm{Bu}$ olumsuz etkiler ve sonuçları, modern teknoloji ile önlenemediği gibi, bu durumun eski haline dönüştürülmesi de mümkün görünmemektedir. Nitekim insan elinin değmediği mekânlar her geçen gün biraz daha azalmakta ve bu nitelikteki alanların önemi gün geçtikçe artmaktadır. Sanayileşme ile ortaya çıkan çevresel sorunlar, hava, su vb. gibi kirlilikler ve trafik sorunu gibi diğer faktörlerin insan sağlığına olumsuz etkileri, insanların doğaya çıkma, doğaya geri dönme, doğa etkinliklerine katılma, kırsal alanlara yönelme ihtiyacını arttırmaktadır (Karaküçük, \& Gürbüz, 2007; Y1lmaz, \& Gürol, 2012, 23-32).

Günümüzde küreselleşmenin etkisiyle nüfus metropollerde yoğunlaşmakta, hızlı tempolu işler yaygınlaşmakta, ileri teknolojik ve makineleşmiş daha bireysel ve kültürel bağlllıktan yoksun yaşam biçimleri ortaya çıkmakta ve bunların sonucunda birçok kişi kendini parçalanmış ve kimliksiz hissetmektedir. Bazı yazarlar bu durumların insanlarda gerçeklerden kaçış (escapism) ve bir anlam arayışı içine girmek ihtiyacına yol açtığını ve bu ihtiyaçları karşılamak için insanların çaba sarf ettiklerini iddia etmektedir. Birçok insan bu ihtiyaçlarını geçmişiyle bağ kurmak, köklerini aramak ve daha sade bir hayatı deneyimlemek için kırsal mekânlarda gidermektedir (George, et alii, 2009, 7-9).

Sadece ekonomik, sosyal, kültürel, çevresel ve siyasi gelişmelerden kaynaklanan değişimler değil bunların yanında daha genel anlamda tüketim ve ulaştırma alanlarında meydana gelen küresel dönüşüm örüntüleri insanların ihtiyaçlarını yeniden şekillendirmekte ve kırsal alanın tüketimine vurgu yapmaktadır (George, et alii, 2009, 1-2). Kırsal alan genel olarak kent ve kasabaların dışında yer alan coğrafi bölgedir. Kırsal alan özellikle çeşitli türden spor ve hobilerle ilişkili olan heves ve sosyalliklerin yeridir veya nesnesidir (Urry, 1999, 301).

Sosyal bağların zayıf ve ayrık olduğu modern dünyanın karmaşıklığına bir tepki olarak kırsal alanlar ve mekânlar yeni bir sosyalleşme veya toplumsal kimlik bulma imkânı sunmasından ötürü yakın sosyal ilişki, samimi ve gerçek değerler ve köklere hasret modern kentli insanlar tarafindan tercih edilmektedir. Bu noktada psikolojik ve fizyolojik olarak yemeği kültürel bir form olarak bütünleştiren gastronomi önem kazanmaktadır. Dolayısıyla kırsal turizmi ve onun bir alt başlığı olan gastronomiyi araştırmak, bizlere kırsal mekânların kaybolan kimliğini geri kazandıracak bir imaj çizmesi ve eski iyi günleri temsil etmesi nedeniyle önemlidir. Günümüzde modern insan, kırsal bölgenin geleneklerin özünü temsil etmesine ve kırsal bölgede ulusal alışkanlık ve tatları bulabileceğine dair bir inanışa sahiptir. Kırsal bölgede yaşayan köylülerin hayatları modern insanların kayıp köklerini bulacakları bir sığınak ve otantiklik kaynağı olarak görülmektedir (Bessiere, 1998, 21-34).

Urry, mekân tüketimi ile mal ve hizmet tüketiminin birbiriyle ilişkili olduğunu belirtmiş ve bu kavramların karşılıklı bağımlı olduklarını üç durumla özetlemiştir. Birincisi yer imajları mal ve hizmetlerin simgesel yerleşiminde rutin olarak kullanılmaktadır. İkincisi özel yerlerde yaşamak 
veya ziyaret etmek çoğunlukla başka tüketim türlerini gerektirmektedir. Üçüncüsü belirli ürünler ve hizmetler sadece özel bir yeri ziyaret ederek elde edilebilir. Sonuçta yer imajlarının kendileri anlamlı biçimde, belirli yerlerde bulunabilen belirli ürün ve hizmetlerle kurulmaktadırlar. $\mathrm{Bu}$ nedenle tüketilen mallar, hizmetler ve yerler arasında karmaşık bağımlılıklar vardır ve belirli yerlerde örgütlenmiş toplumsal yaşam örüntüleri onları birbirine bağlar (Urry, 1999, 47). Bu bağlamda kırsal mekânların tüketimi ele alınırken bu mekânlara özgü yiyecek ve içeceklerin tüketimi de öne çıkmaktadır. Bessiere'e (1998, 21-34) göre yemek fizyolojik olduğu kadar sosyal çevrenin de bir parçasıdır. Aynı zamanda yemek bir topluluk işaret ettiğinde, sınıfsal bir belirleyici olduğunda ve bir amblem olarak kullanıldığında sembolleşebilmektedir.

Günümüzün modern kent sakinleri günlük rutinlerinden kaçarak teselliyi yöresel ya da bir başka deyişle geleneksel yemeklerinde aramaktadır. Günümüzde yemek ve mutfak konusunda bir geriye dönüş yaşanmaktadır. Artık kırsal mutfaklar ve doğal ürünler popülerleşmiştir (Bessiere, 1998, 21-34). Yöresel yemek kavramı, kırsalda ya da şehir merkezlerinde gelenek haline gelmiş, özel günlerde daha çok tüketilen, genellikle bir olay sonucunda kültüre yerleşmiş ve halk tarafından diğer yemeklerden üstün tutulan yiyecekler olarak tanımlanmaktadır (Hatipoğlu, 2013, 7).

Fischler (1993) “doğaya geri dönme efsanesini” kentlileşme eğilimine karşıt bir görüş olarak ortaya atmıştır. Bu görüş doğayı yönetip kontrol altına alan insan görüşüne karşıttır. Doğaya geri dönüş görüşü doğaya ve geçmişe derin bir özlemi yansıtır. Doğaya ve geçmişe özlem duymak ise kent hayatının bir tamamlayıcısıdır. Modern kent insanları hafta sonları yakın kırsal alanlara giderek ve bazen evini kırsal evler gibi dekore ederek (rustik tavan kirişleri, şömine) bu özlemi gidermeye çalışır (akt. Bessiere, 1998, 21-34). Kentli insanlar bir süreliğine de olsa kent hayatının tükenmişlik hissinden kaçmak için kırsal alanları tercih etmektedirler (Arahi, 1994, 3-8).

Günümüzde kırsal alanlarda tarım sektörünün ekonomik ve istihdam açısından azalmasıyla birlikte, kırsal alanların farklı bir şekilde değerlendirilmesi meselesi gündeme gelmiştir. Bunun bir yolu da kırsal alanların turizm açısından değerlendirilmesi meselesidir. Buna alan yazınında kırsal turizm veya eko turizm denilmektedir (Storey, 2006, 1-2). Kırsal veya eko turizmin geçmişi 1980'li yıllara dayanmaktadır. Kırsal turizm, tahrip edilmemiş, kirletilmemiş doğal alanlarda hoşça vakit geçirmek, gözlem yapmak, doğayla baş başa olmak amacıyla tarımsal veya yerel değerlerle iç içe bulunarak vakit geçirmek isteyen turistlere, beklentileri doğrultusunda konaklama, yiyecek-içecek ve diğer hizmetleri veren küçük ölçekli işletmelerin yer aldığ1 küçük yerleşim yerlerinde gerçekleştirilen faaliyetler bütünüdür. Turizm için kırsalın taşıdığ anlam, deniz turizm merkezleri dışında kalan, kentsel yerleşimlerden uzakta, kırlara özgü doğal ve kültürel yapının korunduğu ve yapaylıktan uzak (otantik) alanlardır (Greffe, 1994, 23-40; Fennell, 2007, 40; Çolak, 2009, 35). Günümüzde ulaşım teknolojisindeki gelişmelerle birlikte geleneksel turizm tanımındaki en az 24 saatliğine evden uzak bir çevrede olmak tanımı, günübirlik yapılan ziyaretleri de turizm tanımı kapsamına almaktadır (Hall, 2008, 11-12). Kırsal turizm, ziyaretçinin evinden kilometrelerce uzaktaki bir ülkede uzun bir tatil ya da birkaç dakikalık uzaklıktaki kırsal alanda öğleden sonra gezisi şeklinde olabilir (Aydın, 2012, 39-46). Günümüzde kentli insanların boş zamanlarının eskisine nazaran daha fazla olmasıyla birlikte kırsal turizme ilgi giderek artmaktadır (Storey, 2006, 4).

Alan yazınında kırsal/eko turizm aktivitesi gerçekleştiren ziyaretçilerin amacının şunlar olmasi gerektiği belirtilmektedir (Fennell, 2007; Hall, 2008).

1. Seyahat gerçekleştirilen yerel bölgedeki doğal çevrenin korunmasına katkı yapmak.

2. Seyahat gerçekleştirilen yerel bölgedeki yerel kültürel değerlerin ve kaynakların korunmasina katk1 yapmak. 
3. Seyahat gerçekleştirilen yerel bölgenin ekonomik gelirine, iş imkânlarının artırılmasına, büyümesine ve diğer sektörlerin gelişmesine katkı yapmak.

Kırsal turizm ya da eko turizm kavramının bir de eleştirel yönü bulunmaktadır. Eko turizme eleştirel bakan araştırmacılar aslında kırsal/eko turizmin yerel halkın refahına katkı yapamad1ğını ve doğayı korumada istenildiği kadar başarılı olamadığını iddia etmektedirler. Onlara göre eko turizm daha çok turistlerin egosunu tatmin etmeye yönelik bir faaliyettir. Bu araştırmacılara göre eko turistlerin çoğunun amacı doğal alanlara olan etkiyi minimal düzeyde tutmak değil aksine artık günümüzde çok şey ifade eden kişisel bir imaj yaratmaktır. Eko turizm artık bir statü sembolüdür (Munt, 1994, 49-60; Maccannell, 2002, 146-151; Weaver, 2002, 251-264; Ar1, 2009, 8-9). Urry (1995) ise kırsal mekânların günümüzde aynı birer ticari meta gibi pazarlanabilir bir konuma geldiğini iddia etmektedir (Storey, 2006, 2).

\section{Kentli Bireylerin Kırsal Bir Tüketim Mekânı Olarak Antalya Çakırlar Bölgesi}

Antalya günümüzde Türkiye'nin ve dünyanın önemli turizm merkezlerinden biridir. Türkiye'nin en çok turist çeken kenti olan Antalya'ya 2013 yılında 11 milyonu aşkın yabancı turist gelmiştir (www.ktbyatirimisletmeler.gov.tr/TR,9854/sinir-giris-cikis-istatistikleri.html). Antalya, deniz, kum, güneş turizminin yanı sıra yıl boyu süren kültür turizmi, golf turizmi, spor turizmi (özellikle futbol), kongre turizmi, yat ve rafting turizmi, dağ ve safari turizmi, av turizmi, yayla turizmi, kış turizmi ve sağlık turizmi alanlarında büyük hareketliliğe ve canlılığa sahiptir (Antalya İl Kültür ve Turizm Müdürlüğü, 2012). 2013 yılı adrese dayalı nüfus sayımına göre Antalya kenti büyükşehir nüfusu 2.158.265'dir (www.tuik.gov.tr/PreTablo.do?alt_id=1059).

Antalya kenti ve merkez ilçelerinden biri olan Konyaaltı, doğal güzellikleri ve sosyal alanları açısından zengin bir bölgedir. Antalya'nın önemli sosyal alanlarından olan Büyük Liman, Serbest Bölge, Konyaaltı Plajları, Saklıkent Kayak Merkezi, Topçam ve Çaltıcak Günübirlik Sahil Mesire Alanları, Tünektepe (manzara seyri) ilçe sınırları içerisinde bulunmaktadır (Antalya İl Kültür ve Turizm Müdürlügü, 2012). Yine ilçe sınırları içinde yer alan, kent merkeziyle kırsal alanın kesiştiği ve tam anlamıyla kentleşmenin olmadığı Çakırlar Mahallesi bulunmaktadır. Çakırlar Mahallesi, Akdamlar, Geyikbayırı ve Hacısekiler köylerinin ortak sınırına ve oradan da kentin önemli yayla mekânlarından olan Çağlarca'ya çıkan bir güzergâhta yer almaktadır. Yaylaya çıkan bu güzergâh üzerinde Akdamlar, Geyikbayırı ve Hacısekiler köylerinin ortak sınırları yaylada yerleşimin olmasından bu tarafa bir dinlenme ve duraklama alanı olmuştur. Zamanla gözleme ve kahvaltı veren duraklama mekânlarının, bahçelerde yetiştirilen meyve ve sebzenin satıldığ tezgâhların arttığı bu alanın tümü halk arasında "Çakırlar" olarak anılmaktadır.

Çakırlar, Antalya'da yaşayan kentli bireylerin ve Antalya'ya tatile gelenlerin özellikle hafta sonları kahvaltı etmek için tercih ettiği mekânların başında gelmektedir. Bölgede kahvaltı yapılabilecek gözleme ve köy kahvaltısı veren onlarca işletme bulunmaktadır. Mekânlarda mönüler genelde birbirine benzemekte ve bal, peynir, zeytin, reçel gibi kahvaltılıkların yanı sıra; kaşarlı bazlama, tereyağda yumurta, odun ateşinde demleme çay ve gözleme çeşitleri bulunmaktadır. Yöre halkının kendi bahçelerinde ürettikleri portakal, limon, mandalina, nar, domates ve biber olmak üzere birçok taze ürün geçiş güzergâhında bulunan pazardan satın alınabilmektedir. Mekânın ormanlık alan içinde bulunmasından dolayı doğa yürüyüşü yapmak için de uygundur (www.fullantalya.com/gozleme-ve-nar-suyu-cumhuriyeti-cakirlar/).

Son 15-20 yıldır Antalya içerisinde yaşayan kentli bireylerin günübirlik vakit geçirmek için Çakırlar bölgesini tercih ettikleri gözlemlenmektedir. Çakırlar, bir metropol olan Antalya kentinde (Garipağaoğlu, 2010, 25) günübirlik vakit geçirilebilecek yakınlıkta (yaklaşı $11 \mathrm{~km}$ ) yer 
alan kırsal mekân özelliği göstermektedir. Özellikle son yıllarda bu kırsal mekâna olan yoğun talep araştırmacıların dikkatini çekmiştir. Bu nedenle mekânın, kentli bireylerin günlük yaşamda kırsal mekân tüketimine yönelik bir araştırma için uygun olacağı düşünülmüştür. Araştırma yapılan mekânın seçilmesinde, Antalya kentinin doğal güzellikleri olan bir metropol olması, kent merkezine yakın mesafede kırsal mekânların bulunması ve bu mekânlar içinde en çok tüketilen kırsal mekânın Çakırlar olması koşulları etkili olmuştur.

\section{Araştırma Metodolojisi ve Bulgular}

\subsection{Tasarım}

Araştırmada yöntem olarak nitel araştırma deseni kullanılmıştır. Bunun sebebi çalışmanın istatistiksel bir analizden çok bireylerin bir olguyla ilgili algılamaları ve varsayımlarıyla ilgilenmesidir. Nitel araştırma desenini kullanan araştırmacılar olguları doğal ortamında araştırır, olguya insanların yüklediği anlamları yorumlamaya çalışır (Silverman, 2005, 7-8; Creswell, 2007, 42-44). Bu araştırma kentli bireylerin kırsal mekân ve kırsal mekân tüketimiyle ilgili algılamalarını anlamayı ve açıklamayı amaçlamaktadır. Araştırmada veriler bireysel görüşme ve gözlem yöntemiyle toplanmıştır. Görüşme yöntemi araştırmaya katılan her bir bireyin sosyal gerçekliğe ilişkin bilgilerini, kavramlarını, görüşlerini, deneyimlerini, etkileşimlerini ve anlamlandırmalarını anlayabilmek ayrıca konu ile ilgili bireysel algıların derinine inmek amacıyla kullanılmıştır. Görüşme yöntemini kullanan araştırmacı görüşme yapılan kişinin içsel dünyasına girmeye ve olayları onun perspektifinden anlamaya ve kavramaya çalışır. Gözlem ise olguyu daha iyi anlamak için araştırmanın doğal ortamında sözlü olmayan davranışları incelemek ve veri setini zenginleştirmek amacıyla yapılmıştır (Silverman, 2005, 109-113).

\section{2. Örneklem}

Kentli bireylerin kırsal mekân algıları ve kırsal mekân tüketimlerini betimleyebilmek amacıyla iki ayrı katılımcı grubu belirlenmiştir. Öncelikle araştırmanın amacı doğrultusunda araştırmanın örneklemini kırsal mekânı tüketen kentli bireylerin oluşturması planlanmıştır. Fakat araştırmanın nitel veri setini zenginleştirmek amacıyla kırsal mekânı tüketen bireylerin kırsal mekân bağlamında sürekli etkileşimde oldukları ve onlara hizmet sunan taraf olan kırsal mekân sahiplerinin, kırsal mekânı tüketen kentli bireylerle ilgili görüşlerinden yararlanmak amacıyla bu grup da örnekleme dâhil edilmiştir. Bu bağlamda araştırma örnekleminin niteliğini Antalya Çakırlar bölgesinde kır/köy kahvaltısı hizmeti veren mekânların sahipleri ve bu mekânları tüketen bireyler oluşturmaktadır. Bölgede aktif olarak kır/köy kahvaltısı hizmeti veren yaklaşık 80 mekân bulunmaktadır. Bölgedeki mekânları tüketenlerin yaklaşık sayısı Çakırlar Mahallesi muhtarından elde edilmiştir. Muhtarın verdiği bilgiye göre hafta sonları bölgeye yaklaşık 10.000 araç gelmekte, bu da yaklaşık 30.000 bireye tekabül etmektedir.

Araştırma kapsamında belirlenen iki ayrı katılımcı grubundan mekân sahipleri örneklemi için amaçlı örnekleme yöntemlerinden benzeşik örnekleme yöntemi kullanılmış, mekânı tüketen bireylerin oluşturduğu örneklem için yine amaçlı örnekleme yöntemlerinden kolay ulaşılabilir durum örneklemesi kullanılmıştır (Tashakkori, \& Teddlie, 2003, 355-359). Mekân sahipleri için benzeşik örnekleme yönteminin kullanılmasının sebebi, kapasite, büyüklük, işletme yaşı ve tecrübe açısından benzer mekânların örnekleme dâhil edilmek istenmesidir. Mekânı tüketen bireyler için kolay ulaşılabilir durum örneklemesinin kullanılmasının sebebi, araştırmacıların kolay erişebileceği bireylerin örnekleme dâhil edilmek istenmesidir (Yıldırım, \& Şimşek, 2011, 113).

Nitel araştırmalarda örneklem büyüklüğünü tespit etmede etkili olan ilkelerden biri kuramsal örneklemedir. Buna göre araştırma sorularının yanıtı olabilecek kavramların tekrar etmeye baş- 
ladığı aşamaya kadar veri toplamak amaçlanmıştır. Bu bağlamda örneklem büyüklüğü mekânı tüketen bireylerden oluşan grup için gönüllü 15 katılımcıdan, mekân sahiplerinden oluşan grup için gönüllü 7 katılımcıdan oluşmaktadır. Görüşme yapılan mekânı tüketen bireylerden 8'i kadın, 7'si erkek ve mekân sahiplerinden ise 6'sı kadın, 1'i erkektir. Araştırma katılımcılarının ayrıntılı demografik özellikleri Tablo 1'de gösterilmektedir.

Tablo 1. Araştırmaya Katılan Bireylerin Demografik Özellikleri

\begin{tabular}{|l|c|c|}
\hline Demografik Özellik & Mekânı Tüketenler (N) & Mekân Sahipleri (N) \\
\hline Cinsiyet & & \\
\hline Kadın & 8 & 6 \\
\hline Erkek & 7 & \\
\hline Yaş & & 0 \\
\hline $25-30$ & 3 & 1 \\
\hline $31-35$ & 6 & 1 \\
\hline $36-40$ & 0 & 4 \\
\hline $41-45$ & 3 & 0 \\
\hline $46-50$ & 1 & 1 \\
\hline 51 ve üstü & 2 & 6 \\
\hline Ĕgitim & & 1 \\
\hline Orta Öğretim & 1 & 0 \\
\hline Lise & 2 & 0 \\
\hline Lisans & 7 & 0 \\
\hline Yüksek Lisans & 2 & 0 \\
\hline Doktora & 3 & 0 \\
\hline Meslek & & 0 \\
\hline Ev Hanımı & 2 & 0 \\
\hline Akademisyen & 4 & 0 \\
\hline Mühendis-Mimar & 2 & \\
\hline Devlet Memuru & 5 & \\
\hline Serbest Meslek & 1 & \\
\hline Diğer & 1 & \\
\hline & & \\
\hline
\end{tabular}

\subsection{Veri Toplama}

Mekân sahipleri ve mekânı tüketen bireyler olarak belirlenen iki grup için iki ayrı yarı yapılandırılmış görüşme formu hazırlanmıştır. Bölgeyle ilgili ön bilgi almak amacıyla mahalle muhtarıyla da görüşme yapılmıştır. Mekân sahiplerine 4 temel başlık altında 15 soru, mekânı tüketen bireylere ise 1 soru demografik bilgileri içerecek şekilde toplam 16 soru yöneltilmiştir. Gerçekleştirilen derinlemesine görüşmeler katılımcılardan izin alınarak ses kayıt cihazına kaydedilmiştir. Görüşme kayıtları deşifre edilerek bilgisayar ortamında yazılı hale getirilmiştir. Her bir görüşme yaklaşık olarak 30 dakika sürmüştür.

Katılımcı gruplarıyla görüşmeler yapılmadan önce internet üzerinden bölgeyle ilgili ön araştırma yapılmıştır. Bölgenin yerlisi olan ve aynı zamanda bölgedeki kentsel dönüşümle ilgili komisyonda görev yapan Çakırlar Mahallesi muhtarı ile ön görüşme yapılmıştır. Muhtar, Çakırlar bölgesine yönelik gözlemini ve çeşitli bilgileri aktarmıştır. Ayrıca katılımcılarla görüşmek için bölgeye gidildiğinde bireyler ve mekânlar üzerine gözlemler yapılmıştır.

Araştırma kapsamında kırsal mekânı tüketen bireylere yöneltilen sorular genel olarak şu kapsamdadir:

a) Neden Çakırlar bölgesini tercih ediyorsunuz? Size ne anlam ifade ediyor? 
b) Çakırlar bölgesine kahvaltı etmek amaçlı giden diğer insanlar hakkındaki gözleminiz ve düşünceleriniz nelerdir? Sizinle benzer / farklılaşan yönleri nelerdir?

c) Çakırlar bölgesi ile şehir merkezi veya yaşadığınız semt farklılık gösteriyor mu, örneklendirebilir misiniz?

Mekân sahiplerine yöneltilen sorular ise genel olarak şu çerçevededir:

d) Çakırlar bölgesi hakkında genel bilgi verir misiniz (Toplam işletme sayısı, vb.)?

e) Size gelen müşterileriniz hakkında bilgi verir misiniz? (müşteri profili, nereden geliyorlar, şehir/köy..)

f) Müşteriler neden Çakırlar bölgesini tercih ediyorlar?

g) Müşterilerinizle ilişkileriniz nasıldır? Müşteriler neden sizin işletmenizi tercih ediyorlar?

\subsection{Analiz ve Bulgular}

Öncelikle kayda alınmış olan görüşmeler birebir yazıya geçirilmiştir. Araştırmanın geçerliliği ve güvenilirliği için nitel araştırma yöntemi konusunda deneyimli iki akademisyenin yapılan araştırmayı çeşitli boyutlarıyla incelemesi istenerek uzman teyidine başvurulmuştur. Uzmanlardan içerik analizi ve araştırma tasarımı hakkında geri bildirim alınmıştır. Uzmanların ve araştırmacıların metinlerde saptadıkları ana ve alt temalar arasında yüksek oranda benzerlik görülmesi, araştırmanın geçerliliğine ve güvenilirliğine katkı sağlamıştır.

Verileri açıklayabilecek kavramlar önceden belirlenmiş temalardan değil, görüşmelerden elde edildiği için içerik analizi kullanılmıştır. Mekân sahipleri ve bireylerden toplanan verilerden tümevarım yöntemiyle benzer ifadeler gruplandırılmış ve böylece ana ve alt temalar ortaya çıkarılmıştır. Dolayısıyla bu araştırmada yapılan kodlama verilerden çıkarılan kavramlara göre yapılmıştır.

Araştırma bulgularına göre 5 ana tema ve 7 alt tema belirlenmiştir. Bunlar, doğallık ve sağlık (doğallık, doğal gıda, mekânın sağlıklı ve huzurlu olduğu algıs1), samimiyet (samimi ortam, bireylerin rahat tavırlarına imkan vermesi), nostalji ve otantiklik (mekânın geçmişi hatırlatması, otantik ortam), kentten uzaklaşma ve sosyal ortama katılımdır. Ana temalar, alt temalar ve bu temalara ilişkin alıntılar Tablo 2'de gösterilmektedir. Her bir temaya ilişkin alıntılar, alıntı yapılan katılımcının mekânı tüketen (MT) veya mekân sahibi (MS) olduğu belirtilerek numaralandırılmıştır.

Tablo 2. Kırsal Mekân Tüketimine Yönelik Temalar

\begin{tabular}{|c|c|c|}
\hline $\begin{array}{c}\text { Ana } \\
\text { Tema }\end{array}$ & Alt Tema & Alıntılar \\
\hline \multirow{2}{*}{ 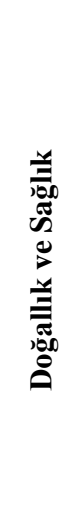 } & Doğallık & $\begin{array}{l}\text {...bizim yerimizin yol kenarı olmadığını, sakin, yeşillikler içinde ve daha temiz olduğunu } \\
\text { söylüyorlar (MS*:7). Yani sıkılmıyoruz. Ortam natürel (MT*:12). Orman, temiz hava, } \\
\text { oksijen, doğal ortam (MT:13). Çakırlardaki tabiat daha güzel ve orası şehir kadar kalaba- } \\
\text { lık değil (MT:2). Antalya için bir diğer anlamı da, deniz kentinde insana dağ esintisi ver- } \\
\text { mesi (MT:5). Doğa güzelliği, çok beğendim (MT:11). Burası daha yeşillikler içinde oldu- } \\
\text { ğundan daha huzur buluyoruz Yeşilliklerin arasında işte. Farklı (MT:12). ...çocukları me- } \\
\text { sela betondan sıkılıyoruz diyor herkes, buraya geliyor doğallı, kahvaltı 2-3 saat oturup } \\
\text { gidiyorlar (MS:6). }\end{array}$ \\
\hline & Doğal Gıda & $\begin{array}{l}\text { Pazar daha doğal çünkü köylüler kendi ürünlerini satıyorlar (MT:3). İçim oldukça rahat } \\
\text { olarak geliyorum, her şey lezzetli, güzel en önemlisi doğal (MT:8). ...kahvaltının doğal } \\
\text { olması (köy yumurtası, peyniri, balı...) tercih nedeni sanırım (MT:5). Büyük bir çoğunlu- } \\
\text { ğun organik olduğunu düşündüm nar-portakal gözünüzün önünde sık1lıyor tarhanayı kendi } \\
\text { imkânları ile paketlemişler mesela, doğal ve organik olduğunu düşündüm (MT:9). }\end{array}$ \\
\hline
\end{tabular}




\begin{tabular}{|c|c|c|}
\hline & $\begin{array}{l}\text { Mekânın } \\
\text { sağlıklı ve } \\
\text { huzurlu } \\
\text { olduğu algısı }\end{array}$ & $\begin{array}{l}\text { Temiz hava oksijen için geliyorlar bence (MT:6). Çakırlar'da doğanın içinde ve ormanın } \\
\text { içinde hissi var (MT:7). Burası sessiz, çocuklar oynayabiliyor (MS:5). Temiz hava, bol } \\
\text { yeşillik, şehir gürültüsünden uzakta sakin bir ortam ifade ediyor (MT:2). Kuralların olma- } \\
\text { dığı, insanların geçmişinden getirdiği bazı şeyleri yakalayabildiği (tavuk sesi, rüzgâr sesi, } \\
\text { toprak kokusu) oksijen oranının yüksek olduğu sakin bir ortam olmasıdır (MT:2). }\end{array}$ \\
\hline \multirow[t]{2}{*}{ 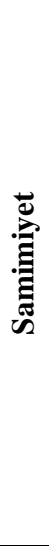 } & $\begin{array}{c}\text { Samimi } \\
\text { Ortam }\end{array}$ & $\begin{array}{l}\text { Orada bir halkla ilişkiler başarısı var bence, o dili iyi kurabildiği için hem şehirli insanları } \\
\text { yakalıyor hem de doğal ortam sağlayan insanları yakalıyor (MT:1). Çok doğal, insanlar } \\
\text { daha sıcak (MT:6). ...bizim hep kapımız penceremiz açıtır. Hepimiz art niyetsiz insanla- } \\
\text { rız. Böyle bizim köylerimiz gibi başka yerde yoktur, yurtdışında falan. Buraya gelen de } \\
\text { benim dürüstlüğüme geliyor (MS:3). Hazır aldığım ürünü söylüyorum. Hoşuna gidiyor } \\
\text { müşterinin, kendimiz yapmadıysak söylerim (MS:4). Müşterilerimizle oturup sohbet ede- } \\
\text { riz, ağlaşırız bile. Aramız çok iyidir (MS:3). Henüz gözü açı esnaf hissi yok, bu hoşuma } \\
\text { gidiyor (MT:7). Müşterilerle ilişkilerim çok iyi. } 9 \text { ylldır aynı gelen müşterilerim var. } \\
\text { Sadece sizin güler yüzünüz için geliyoruz diyenler var (MS:2). }\end{array}$ \\
\hline & $\begin{array}{l}\text { Bireylerin } \\
\text { rahat } \\
\text { tavirlarına } \\
\text { imkân } \\
\text { vermesi }\end{array}$ & $\begin{array}{l}\text { İstediğimize göre ürünlerin değişmesi benim için önemli malum çocuk olunca bazen özel } \\
\text { isteklerinizde oluyor, burası bunları karşılıyor (MT:8). Yerlerde oturmak, rahat rahat ya- } \\
\text { yılma. Hem o ortamda oturmak hem de kahvaltıda sunulanlar hoşuma gidiyor (MT:15). } \\
\text { Deniz kenarına göre bu bölgede kendimi daha rahat, daha özgür hissediyorum (MT:6). }\end{array}$ \\
\hline \multirow[t]{2}{*}{ : } & $\begin{array}{c}\text { Mekânın } \\
\text { geçmişi } \\
\text { hatırlatması }\end{array}$ & $\begin{array}{l}\text { Bölge kısmen bir köy... Belki de bu nedenle, şehirli insanın doğa özlemini gideriyor } \\
\text { olabilir (MT:5). Çocukluğumuzda alışmış olduğumuz ortama benzer bir ortam gördüm, } \\
\text { çocukluk yıllarımızı yaşattı bize o ortam (MT:9). Nostalji diyelim, biz nesil olarak hayat } \\
\text { koşturmacası içindeyiz çocukluğumuzda kaldı böyle yerler, hatta bazllarımız sadece } \\
\text { ailesinin anlattığ1 kadarılya biliyor köy yaşamını burada biraz onu buluyorum (MT:4). } \\
\text { Anadolu kadını gibi her şeyi önüne donatıyorlar. Çayını da çaydanlıkla getiriyorlar, köy } \\
\text { kahvaltısı imajını bunlar veriyor zaten (MT:1). Hem manevi zevkimiz hem de damak } \\
\text { zevkimiz orada tatmin olmuş oldu. Çocukluğumda tattı̆ım tatlara yakın tatları, o manevi } \\
\text { anlamda bir haz veriyor ve bir geriye dönüş oluyor (MT:9). }\end{array}$ \\
\hline & $\begin{array}{l}\text { Otantik } \\
\text { ortam }\end{array}$ & $\begin{array}{l}\text { Burası köy, doğal, geleneksel ve huzurlu (MT:4). Geleneksel giyim tarzı olmasa aynı hava } \\
\text { olmaz (MT:3). Orası çakırlar köyü olduğu için orada şalvarlı, yemenili teyzeler, kimisi nar } \\
\text { suyu sıkıyor, kimisi tarhana, salça satıyor, kimi el emeği bir şeyler yapmış, patikler-yelek- } \\
\text { ler örmüş satıyor tabii ki o izlenimi veriyor (MT:9). }\end{array}$ \\
\hline & 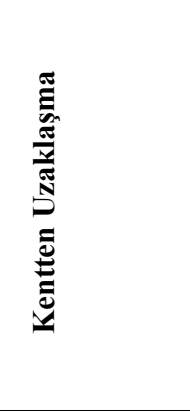 & $\begin{array}{l}\text { Şehir ortamından uzak... Gürültülü değil, hava olarak şehirden faklı. Kapalı ortam değil } \\
\text { (MT:12). Şehrin pis havasından kurtulduğumu hissediyorum orada (MT:13). Manyetik } \\
\text { alanlardan uzakta, AVM'nin manyetik alanını düşünüyorum mesela, insanlar genelde } \\
\text { oralarda vakit geçiriyorlar (MT:1). Bana göre ise AVM benim içimi daraltıyor, oralarda } \\
\text { bir uğultu var (MT:6). Burada o şehir hayatının baskısı yok. Brunch her yerde var, buraya } \\
\text { gelme sebebi doğal ortam, doğal ortamda da içerikleri aynı bile olsa doğal bir isim olmalı } \\
\text { o da "köy kahvaltısı" dır (MT:8). Ben oraya zaten şehrin wirelessından, internetinden, bil- } \\
\text { gisayarından uzaklaşmak için gittiğim için... (MT:13). Yürüyüş yapabiliyorsun dağlara } \\
\text { doğru, bir sürü aktiviteyi bir arada yapabiliyorsun (MT:6). Orada yürüyüş yaptım biraz } \\
\text { açı havada, beni oksijen çarptı dediğim durumlar oluyor (MT:13). Buraya geldiğimde } \\
\text { rahatlıyorum, hafta sonu burada yeniden şarj olup işe öyle başlıyorum adeta (MT:3). }\end{array}$ \\
\hline & 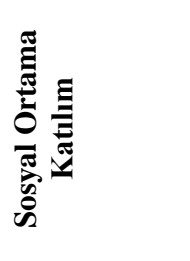 & $\begin{array}{l}\text { Böyle bir yerde insanlar çocukları ya da kalabalık misafirleri ile birlikte daha rahat vakit } \\
\text { geçirebilir (MT:9). Bu bölge benim dinlenmemi sağlıyor, çocuğuma daha iyi vakit ayırd1- } \\
\text { ğımı hissettiriyor (MT:8). Hafta içleri çok yoğun tempoda çalışan insanlar, ailesi ile çok } \\
\text { fazla zaman geçiremeyen, geçirdiği zaman da böyle ender de olsa topluca iyi bir yerlerde } \\
\text { vakit geçirmek isteyen insanlar olduğunu gördüm (MT:14). Çalışan anne-babaların çocuk- } \\
\text { larına zaman ayırmak anlamında tercih edebileceği bir yer, çünkü birçok çocuklu insan da } \\
\text { orada çocuklarıyla vakit geçiriyordu (MT:9). }\end{array}$ \\
\hline
\end{tabular}

*MT: Mekânı Tüketenler, MS: Mekân Sahipleri

1. Doğallık ve Sağlık: Katılımcılar kırsal mekânın fiziksel olarak doğal olması, doğal gıdalara ulaşılabilme imkânı vermesi ve ortamın huzurlu olduğu algısı nedeniyle Çakırlar bölgesinin doğal ve sağlıklı olduğunu ifade etmişlerdir. 
1.a. Doğallık: Katılımcılar mekânın izole olmadığını, mekânın fiziksel görünümünün doğal olduğunu, bu mekânın doğal bir ortam olduğunu, orman ve yeşilliğin bulunduğunu ve bu mekânda çocukların doğal ortamda vakit geçirme ihtiyacını karşıladığını belirtmişlerdir. Bu alt temayla ilgili örnek alıntılar aşağıda belirtilmektedir:

- Deniz kenarında lüks restoranda izole edilmiş alanda insanlar bir rol yapıyorlarmış gibi geliyor bana, dışarida bir trafik var, öteki tarafta bir kavga var, yani modernliğin içinde suni bir bahçe gibi, Çaktrlar bölgesi ise doğal bir bahçe, böceği var, sineği var (MT:1).

- Geliş sebebim birinci öncelik güzellik, doğallı, temiz hava, derenin aklşı olabilir (MT:10).

- Buraya gelen doğaya geliyor. Çoluğunu çocuğunu sallyor buraya. Mesela benim torunlar var apartmanda oturuyorlar çok siklliyorlar. Buraya geliyorlar dünya varmış diyorlar. Okuldan gelip evin içine giriyor, çocuklar şehirde sıkılıyorlar (MS:4).

1.b. Doğal gıda: Katılımcılar mekânda bulunan pazarda taze ve organik gıdaya ulaşabildiklerini ve bunun için bu mekânda sağlıklı beslenebildiklerini belirtmişlerdir. Mekândaki yiyeceklerin yöresel ve ev yapımı olduğunu düşünmektedirler. Ayrıca gıdaların lezzetli olması nedeniyle mekânı tercih ettiklerini belirtmişlerdir. Bu alt temayla ilgili örnek alıntılar aşağıda belirtilmektedir:

- ...burada daha sağglılı beslenip çocuğumu da daha sağllklı beslediğimi düşünüyorum (MT:8).

- Ürünler organik ve doğal, yani ben öyle düşünüyor, öyle zannediyor ve o niyetle yiyorum (MT:3).

- Doğallı̆̆ konusunda bir kuşsütü eksik denilen kahvaltılar var (MT:1).

1.c. Mekânın sağlıklı ve huzurlu olduğu algısı: Katılımcılar kırsal mekânın ormanlık alan içinde bulunması nedeniyle temiz hava aldıklarını, sessiz ve dinlendirici bir ortam olduğunu belirtmişlerdir. $\mathrm{Bu}$ nedenle kendilerini rahat hissettiklerini ve manevi bir tatmin sağladıklarını söylemişlerdir. Bu alt temayla ilgili örnek alıntılar aşağıda belirtilmektedir:

- Sakin, sinek, böcek seslerinden başka bir şey yok, tamamen uzaklaşmak için kullanıyorum ben orayl (MT:1).

- Doğal ortam olduğu için, ağaçlık, yeşillik, benim için sakinlik ve huzur ifade ediyor, buraya geldiğimde rahatlyyorum, hafta sonu burada yeniden şarj olup işe öyle başlıyorum adeta (MT:3).

- O bölge bana huzuru ifade ediyor (MT:1).

2. Samimiyet: Katılımcılar Çakırlar bölgesinin ilişkiler açısından samimi bir ortamı olduğunu ifade etmişlerdir. Bunun yanında rahat davranışlarına imkân veren bir ortam olduğunu belirtmişlerdir.

2.a. Samimi ortam: Katılımcılar Çakırlar bölgesinde, mekân sahiplerinin kendilerine sıcak ve yakın davrandıklarını, yiyecekler ve ikram ile ilgili iyi niyetli olduklarını ve dürüst davranışlarının olduğunu belirtmiş̧lerdir. Kırsal mekânlara gittiklerinde güler yüzlü ve sıcak karşılamaların olduğunu, mekân sahipleri ile tanışık olmanın hoşlarına gittiğini belirtmişlerdir. Katılımcılar mekânların çok profesyonel olmadığını, mekân sahiplerinin ilişkilerinin yapay olmadığını ve gözü açık esnaf algısı yaratmadıklarını söylemişlerdir. Katılımcılar iyi niyet ve dürüstlükle karşılaştıkları için mekânı çocukları için de güvenilir bir ortam olarak bulmaktadırlar. Bu alt temayla ilgili örnek alıntılar aşağıda belirtilmektedir:

- Buradaki her şeyden kendim de yiyorum bir de eşimle dostumla çocuğumla yiyorum onun için güveniyorlar (MS:3).

- Davranışları doğal. Ortam, bir doğal havası oluyor (MT:13). 
- İsletmelerin genelde profesyonel olduğu söylenemez, ama bu da otantiklik duygusu veriyor insana (MT:5).

2.b. Bireylerin rahat tavırlarına imkân vermesi: Katılımcılar kalabalık ve aile olarak mekânda rahat ettiklerini belirtmiş ve kişisel alanların genişliğinden memnun olduklarını söylemişlerdir. Mekânda rahat oturup yemek yiyebilmenin mümkün olduğunu ve salaş olabilme olanağı sağladığını belirtmişlerdir. Fiziksel ve davranışsal olarak rahat ettiklerini söyleyen katılımcılar bu nedenle kendilerini özgür hissettiklerini söylemişlerdir. Bu alt temayla ilgili örnek alıntılar aşağıda belirtilmektedir:

- Rahat bir şekilde yemek yiyebiliyorsun. O yüzden diğer gelen müşterilerle çok fazla muhatap olunmadı̆̆ından onların profili kötü bile olsa tahammül edilebilir oluyor (MT:1).

- Burada rahatsinız işte ister yat, ister bağdaş kur, ister elinle ye ben bu rahatlığı seviyorum (MT:8).

- Doğal bir ortam, salaş bir ortam (MS:6).

3. Nostalji ve Otantiklik: Katılımcılar Çakırlar bölgesinin kendilerine geçmişteki geleneksel yaşamlarını hatırlattığını ve her şeyiyle tam bir köy ortamı olduğunu bu nedenle mekânı nostaljik ve otantik bulduklarını belirtmişlerdir.

3.a. Mekânın geçmişi hatırlatması: Katılımcılar geçmişe, doğaya özlem duyduklarını ve mekânın gelenekselliği nedeniyle bu özlemlerini giderebildiklerini belirtmişlerdir. Bu geleneksel ortamda köy kahvaltısının bulunması ile geleneksel damak tadı özlemlerini giderebildiklerini söylemişlerdir. Bu alt temayla ilgili örnek alıntılar aşağıda belirtilmektedir:

- Ben özlüyorum, otantik bir havası var, köy tarzl, benim yetiştiğim ortama da benziyor ben gecekonduda büyüdü̈̆̈̈̈m için, belki orayı anımsattığı için gidiyorum, bilmiyorum, rahat ediyorum daha doğrusu (MT:6).

- Çocukluğumu hatırlyyorum, nostalji oluyor benim için, ruhuma iyi geliyor buranın sunduğu geleneksellik, anılarımın canlanması... (MT:8).

- O dere kenarında gürül gürül su sesi, köy evi tarzında yapılmış yerler, minderler, kahvaltının yerde yapılıyor olması bizi çok eskilere götürdü, çok güzel anılarımızı canlandirdı (MT:9).

3.b. Otantik ortam: Katılımcılar mekânın bir köy ortamı olması, mekân sahiplerinin ve çalışanlarının şalvar giymeleri ve şiveli konuşmaları nedeniyle mekânı otantik bulduklarını belirtmişlerdir. Bu alt temayla ilgili örnek alıntılar aşağıda belirtilmektedir:

- Şive farklılı̆̆ bile bizlerde olumlu etki yarattyor (MT:10).

- Müş̧eri bir de buranın doğallı̆̆ına geliyor. Şalvar giyilsin istiyorum, kizlar da giyiyor benim... (MS:4).

- Deniz kenarına göre bu bölge... daha otantik geliyor (MT:6).

4. Kentten Uzaklaşma: Araştırmaya dâhil olan katılımcılar kırsal mekânı başlıca tüketme nedenlerinden biri olarak kentten uzaklaşma ihtiyacını vurgulamışlardır. Buna göre kırsal mekânı tüketenler, kapalı ve gürültülü kent mekânlarından uzak kalma, AVM'den kaçma, şehir hayatının baskısından ve teknolojiden -özellikle internet ve bilgisayardan- uzaklaşma ihtiyaçlarının olduğunu belirtmişlerdir. Ayrıca katılımcılar Çakırlar bölgesinin açık hava bir mekân olması, doğada spor yapmaya elverişli olması ve farklı mekân tüketme ihtiyacını karşılaması nedeniyle tercih ettiklerini de eklemişlerdir. Bu temayla ilgili örnek alıntılar aşağıda belirtilmektedir:

- ...insan orada sadece kahvaltı etmiyor, aynı zamanda şehir hayatından da uzaklaşıyor (MT:5).

- Burası, şehrin stresi, gündelik çalışma hayatından sizi koparıyor, rahatlamanızı sağlıyor 
(MT:14).

- Çocuklarımı oraya götürmek isterim çünkü onları internetin başından birkaç saat kaldırmak benim için büyük bir kâr, orada temiz hava soluyacaklar, sağllklı gıda yiyecekler ve çocuklarımla baş başa zaman geçireceğim bunlar benim için en önemlileri (MT:9).

5. Sosyal Ortama Katılım: Katılımcıların kırsal bir mekân olan Çakırlar bölgesini tercih etme sebeplerinden önemli bir başka neden ise bu kırsal mekânın bireylere sosyal ortama katılım imkânı sunmasıdır. Çakırlar bölgesinin bireylere sosyal ilişkiler kurmaya imkân sağlaması, aile içi ilişkileri güçlendirmeye yardımcı olması, sosyal çevrenin bu bölgeyi tercih etmesi, çocuklara sosyal ortama katılma imkânı vermesi, her kesimden bireyin burayı tercih etmesi, misafirlerin farklı bir mekânda ağırlanma ihtiyacı gibi sebepler kırsal mekânın "sosyal ortama katılım imkânı verme" özelliğini vurgulamaktadır. Bu temayla ilgili örnek alıntılar aşağıda belirtilmektedir:

- Burası aile ilişsilerini, sosyal ilişkileri veya bu tarz ilişkileri güçlendiriyor. Çünkü oraya gittiğiniz zaman tek gitmiyorsunuz ya da bir eşiniz ile gitmiyorsunuz, toplu kişiler ile kalabalık gidiyorsunuz. Bunun da sosyal ilişkileri güçlendirdiğine inaniyorum (MT:14).

- Mesela aynı apartmanda oturanlar var buraya gelmişler tesadüfen. Apartmanda çocuklar diyalog kuruyorlar ya birbirlerini burada tanıdılar onların sayesinde anne-babaları da konuşmuş oldu burada (MS:4).

- ...burayı tercih etme nedenim arkadaşlarımın bu mekânı tercih etmesi (MT:2).

\section{Sonuç}

Günümüzde küreselleşmenin etkisiyle nüfus metropollerde yoğunlaşmakta, bireysel ve kültürel bağl11ıktan yoksun yaşam biçimleri ortaya çıkmaktadır. Bunların sonucunda metropollerde yaşayan birçok birey kendini parçalanmış ve kimliksiz hissetmektedir (George, et alii, 2009, 7-9). Giddens'in (2000) da belirttiği gibi kentlerde yaşayanlar çok fazla hareketli olma eğiliminde olduklarından aralarındaki bağlar göreli olarak zayıftır. Sosyal bağların zayıf ve ayrık olduğu modern dünyanın karmaşıklığına bir tepki olarak kırsal alanlar ve mekânlar yeni bir sosyalleşme veya toplumsal kimlik bulma imkânı sunmaktadır (Bessiere, 1998, 21-34). Bu açıdan bakıldığında bir metropol olan Antalya' da yaşayan kentli bireylerin kırsal mekân ve kırsal mekân tüketimiyle ilgili algılamalarını anlamayı ve açıklamayı amaçlayan bu araştırmanın sonucunda, bir kırsal mekân olan Çakırlar bölgesi ve bu bölgenin tüketimiyle ilgili algılamalar 5 ana tema ve 7 alt tema altında toplanmıştır. Bunlar: 1) doğallık ve sağlık (doğallık, doğal gıda, mekânın sağlıklı ve huzurlu olduğu algısı), 2) samimiyet (samimi ortam, bireylerin rahat tavırlarına imkan vermesi), 3) nostalji ve otantiklik (mekânın geçmişi hatırlatması, otantik ortam), 4) kentten uzaklaşma ve 5) sosyal ortama katılımdir.

$\mathrm{Bu}$ araştırmada içerik analizi sonucu elde edilen temalar önceden alan yazınına göre değil, yapılan görüşmelerin sonucunda belirlenmiştir. Alan yazınındaki kırsal mekânlarla ilgili çalışmalar bu temalarla karşılaştırıldığında, bu çalışmanın bulgularının aşağıda belirtilen çalışmalarla paralellik gösterdiği söylenebilir.

Doğaya geri dönme efsanesini kentlileşme eğilimine karşıt bir görüş olarak ortaya atan Fischler'e (1993) göre bu görüş doğaya ve geçmişe derin bir özlemi yansıtmaktadır. Doğaya ve geçmişe özlem duymak ise kent hayatının bir tamamlayıcısıdır. Modern kent insanları hafta sonları yakın kırsal alanlara giderek bu özlemi gidermeye çalışmaktadır (akt. Bessiere, 1998, 2134). Bu bulgular çalışma sonucunda elde edilen doğallık ve sağlık, nostalji ve otantiklik temalariyla paralellik göstermektedir.

Besseire'ye (1998) göre sosyal bağların zayıf ve ayrık olduğu modern dünyanın karmaşıklığına bir tepki olarak kırsal alanlar ve mekânlar yeni bir sosyalleşme veya toplumsal kimlik 
bulma imkânı sunmasından ötürü yakın sosyal ilişki, samimi ve gerçek değerler ve köklere hasret modern kentli insanlar tarafindan tercih edilmektedir. Ayrıca kırsal bölgede yaşayan köylülerin hayatları modern insanların kayıp köklerini bulacakları bir sığınak ve otantiklik kaynağı olarak görülmektedir. Bunun yanında günümüzün modern kent sakinleri günlük rutinlerinden kaçarak teselliyi yöresel ya da bir başka deyişle geleneksel yemeklerinde aramaktadır. Günümüzde yemek ve mutfak konusunda bir geriye dönüş yaşanmaktadır. Artık kırsal mutfaklar ve doğal ürünler popülerleşmiştir. Bu bulgular içerik analizi sonucu elde edilen, sosyal ortama katılım, samimiyet, nostalji ve otantiklik temalarıyla ayrıca bu bölgenin bazı katılımcılar tarafindan "geleneksel köy kahvaltısı ve gözleme" için tercih edilen bir mekân olduğu algisıyla da paralellik göstermektedir.

George (et alii, 2009, 5-8) ise metropolde yaşamanın zorluklarının insanlarda gerçeklerden kaçmak ve bir anlam arayışı içine girmek ihtiyacına yol açtı̆̆ını ve bu ihtiyaçları karşılamak için insanların çaba sarf ettiklerini belirtmektedir. Birçok insan bu ihtiyaçlarını geçmişiyle bağ kurmak, köklerini aramak ve daha sade bir hayatı deneyimlemek için kırsal mekânlarda gidermektedir. Bu bulgular çalışma sonucunda elde edilen nostalji ve otantiklik ile kentten uzaklaşma temalarıyla kısmen paralellik göstermektedir.

Alan yazınında yer alan yukarıdaki üç farklı çalışmanın bulgularıyla paralellik gösteren araştırma sonuçlarının yanında bu araştırmanın özgün taraflarından biri, tek bir araştırma sonucunda elde edilen 5 ana temanın bu çalışmaların bulgularının hepsini kapsamasıdır. $\mathrm{Bu}$ araştırmanın kentli bireylerin kırsal mekânları neden ve nasıl tükettiklerinin daha iyi anlaşılmasına katkı sağlayacağı düşünülmektedir. Özellikle uluslararası alan yazınında bu konudaki çalışmaların sayı bakımından oldukça az olması bu araştırmanın önemini artırmaktadır. Ulusal alan yazınında ise çoğunlukla kentli bireylerin kentsel mekânlarla (Örneğin AVM'ler, rezidanslar, plazalar, kafeler) ilgili tercihleri ve algılamaları araştırılmış, kırsal mekân tercih ve algılamalarına neredeyse hiç yer verilmemiştir. Bu nedenle amacı kentli bireylerin kırsal mekân ve kırsal mekân tüketimiyle ilgili algılamalarını anlamak ve açıklamak olan bu çalışmanın alan yazınında bu konuyla ilgili boşluğu kısmen de olsa doldurmak iddiası bulunmaktadır.

Yukarıda değinilen çalışmaların haricinde alan yazınında ayrıca kırsal / eko turizmi konu alan çalışmalardan da bahsedilmesi yararlı olacaktır. Bu çalışmalarda kırsal / eko turizm aktivitesi gerçekleştiren ziyaretçilerin amacının seyahat yapılan yerel bölgedeki doğal çevrenin, kültürel değerlerin, kaynakların korunmasına ve yerel bölgenin ekonomik gelirine, iş imkânlarının artırılmasına, büyümesine ve diğer sektörlerin gelişmesine katkı yapmak olduğu belirtilmektedir (Fennell, 2007, 207-210; Hall, 2008, 11-12). Çakırlar bölgesinin de günübirlik bir kırsal turizm alanı olduğu söylenebilir. Fakat bu noktada çarpıcı olan bulgu, bu araştırmaya katılan katılımcılardan, 1 kişi hariç, yukarıda belirtilen amaçların hiçbirisini belirtmemiştir. Dolayısıyla bu sonuç akla, kırsal turizme/eko turizme eleştirel bakan araştırmacıların aslında kırsal turizmin yerel halkın refahına istenildiği kadar katkı yapamadığ 1 ve doğayı korumada istenildiği kadar başarılı olamadığ iddialarını getirmektedir. Onlara göre kırsal turizm/eko turizm daha çok turistlerin egosunu tatmin etmeye yönelik bir faaliyettir (Munt, 1994, 49-60; Maccannell, 2002, 146-151; Weaver, 2002, 251-264; Arı, 2009, 8-9). Özünel (2011) Türkiye kapsamlı çalışmasında turizmin hareketlendiği yıllardan itibaren sistemli bir biçimde imha edilen yöresel olanın yerini "yöreselmiş gibi" olana bıraktığını belirtmiş, zamanla üretilen bu yapay otantiklik ve yöresellik algısının içselleştirildiğini ve bu kavramların kimlik algımızın inşasında da başat rol oynadığını ifade etmiştir.

Bir kırsal turizm alanı olan Çakırlar bölgesini ziyaret eden araştırma katılımcılarının büyük bir çoğunluğunun lisans ve üzeri eğitim seviyesine sahip olmasına rağmen çevre ve sürdürü- 
lebilirlik konularına değinmemeleri ve bu bölgeye gitme nedeni olarak yalnızca bireysel ihtiyaçlarını vurgulamaları dikkat çekici bir sonuçtur. Bu noktadaki çelişki bu bölgeye giden bireylerin doğayı sanki bir meta gibi görüp tüketmek için oraya gitmeleri fakat bu bölgedeki doğayı korumak ve sürdürülebilirlik için hiçbir çaba içinde olmamalarıdır. Uğurlu ve Tire'nin (2011) de belirttiği gibi günümüzde bir yandan doğayı sömüren bir anlayış güdülürken diğer yandan doğa, kentin sıkışmışlığında özlenen ve başka bir şeyle yeri doldurulamayan özel bir konuma gelmiştir. Dolayısıyla kırsal bir mekân olarak tüketilen Çakırlar bölgesinde mekânı tüketen bireylerin doğa bilincinin yeteri kadar gelişmediği söylenebilir.

Fiske'nin (2012) belirttiği üzere bireyler mevcut sistemden uzaklaşarak bir ara döneme girip rahatlama yaşamaktadırlar. Rahatlama sağlanan bu ara dönemden sonra yüksek bir motivasyon ile yeniden sisteme dönmektedirler. Araştırmanın bulguları bu görüş ile paralellik göstermektedir. Bireyler kent yaşamından bir gün için uzaklaşıp ertesi gün işlerine daha rahatlamış gittiklerini belirtmişlerdir. Dolayısıyla Çakırlar motivasyon sağlayan bir ara dönem geçirme mekânı olmaktadir.

Ergur'un (2012, 11-67) bahsettiği günümüz Türkiye'sinde metropollerde kentsel ayrışmanın bir işlevi olarak kapalı site, bütünleşik işyeri (plaza) ve alışveriş merkezi kapanma sahalarına gönüllü olarak kapanmış modern kentli insanlara belki de bu steril ve gözetime sürekli tabi alanlardan geçici/uçucu bir çıkış noktası olarak kırsal mekânlar geçici bir özgürleşme alanı olarak algılanarak cazip gelmektedir. Bunun bir örneğinin de bu araştırmanın konusu olan Antalya Çakırlar bölgesindeki kırsal mekânların tüketilmesi eğiliminin olduğu söylenebilir. Görüşme yapılan bireylerin, ortamın ve yiyeceklerin doğallığı üzerine özellikle durmaları, kentlerin sıkıc1 ve boğucu olduğuna vurgu yapmaları bu durumun bir göstergesi olarak yorumlanabilir. Bunun yanında teknolojinin olumsuz etkilerinden yakınmaları, kentten kaçma isteğine ve kent yaşamındaki samimiyetsizliğe çokça değinmeleri steril ve kapalı alanlardan duydukları memnuniyetsizliği göstermektedir. Kentler oldukça kalabalık olmalarına rağmen bu kırsal mekânı tüketen bireyler sosyal ortamlara katılamamaktan ve farklı bir sosyal ortama girememekten yakınmaktadır. Bu mekânın kendilerine sosyal ortama katılım imkânı sağladığını düşünmektedirler. Günübirlik tüketilen bu kırsal mekân bireyleri bir gün bile olsa huzurlu ve mutlu hissettirmektedir. Dolayısıyla Çakırlar bölgesi Antalya metropolünde yaşayan bireyler için geçici/uçucu bir özgürleşme alanı olmaktadır. Mekânda doğal, dolayısıyla sağlıklı yiyeceklerin olması, mekânın ormanlık alan içinde olması, mekânın görüntüsü ile otantik olması ve geçmişi hatırlatması, kalabalık halinde rahatlıkla vakit geçirilebilmesi, sessizliği ve sakinliği kentli bireylerin fiziksel, sosyal ve ruhsal ihtiyaçlarını karşılamaktadır. Araştırmada elde edilen temalarla aynı zamanda kırsal mekân tüketimin temel nedenlerinin de ortaya koyulduğu söylenebilir.

$\mathrm{Bu}$ araştırmanın bazı sınırlılıkları bulunmaktadır. Öncelikle araştırma mekân tüketimi alan yazınını içinde sadece kırsal mekân tüketimini incelemektedir. Yöntem açısından sınırlılıklara bakıldığında ise, nitel araştırma yönteminin kullanılması nedeniyle araştırmanın öznel bir yaklaşımı bulunduğu ve araştırmacıların bakış açısını yansıttığı söylenebilir. Ayrıca bu nitel araştırmanın sonuçlarıyla istatistiki genelleme yapmak mümkün değildir (Yıldırım, \& Şimşek, 2011, 57). Örneklemin sadece bir metropoldeki tek bir kırsal mekândan toplanması da araştırmanın diğer bir sınırlılığını oluşturmaktadır. Bunun yanında görüşmeler bölgenin fazla yoğun olmadığ kış aylarında yapıldığı için mekânı tüketen farklı demografik özellikteki bireylerin olabileceği ve bu bireylerin de farklı görüşler aktarabileceği ihtimali bulunmaktadır. Mekânı tüketen bireyler örneklemi içinde kolay ulaşılabilen ve araştırmaya katılmayı isteyen gönüllü bireylerin yer alması nedeniyle farklı görüş belirtebilecek bireylerin olması ihtimali de bulunmaktadır.

Sonuç olarak bu araştırmanın, kentli bireylerin kırsal mekân ve kırsal mekân tüketimiyle 
ilgili algılamalarını anlamak ve açıklamakla ilgili önemli ipuçlarına ulaştığı ve özellikle buna benzer araştırmaların sayısının artmasının, mekân tüketimi alan yazınına önemli katkılar sağlayacağı söylenebilir.

\section{KAYNAKÇA}

Altan, H. Z. (2008). "Bir Sürgünlük Biçimi: Metropol Yaşamı”. İstanbul Üniversitesi İletişim Fakültesi Dergisi, 34, 1-21.

Arahi, Y. (1994). “On the Farm Inns for Japanese Green Tourism”. Journal of Rural Life Studies, 38/3, 3-8.

Arı, Y. (2009). "Eko Turizm mi Ego Turizm mi? Kazdağı (Balıkesir) Örneği”. V. Ulusal Coğrafya Sempozyumu. Ankara Üniversitesi DTCF Türkiye Coğrafyası Araştırma ve Uygulama Merkezi, 1617 Ekim, Ankara.

Aydın, O. (2012). “AB'de Kırsal Turizmde İlk 5 Ülke ve Türkiye'de Kırsal Turizm”. KMÜ Sosyal ve Ekonomik Araştırmalar Dergisi, 14/23, 39-46.

Aydoğan, F. (2009). “Tüketim Kültürünün Gölgesinde Kentler”. Marmara Üniversitesi İIBF Dergisi, 27/2, 203-215.

Aytaç, Ö. (2006). “Tüketimcilik ve Metalaşma Kıskacında Boş Zaman”. Kocaeli Üniversitesi Sosyal Bilimler Enstitüsü Dergisi, 11, 27-53.

Aytaç, Ö. (2007). "Kent Mekânlarının Sosyo-Kültürel Coğrafyası”. Fırat Üniversitesi Sosyal Bilimler Dergisi, 17/2, 199-226.

Baudrillard, J. (2008). Tüketim Toplumu-Söylenceleri ve Yapıları. Çev.: H., Deliceçaylı, \& F., Keskin. İstanbul: Ayrıntı Yayınları.

Bessiere, J. (1998). "Local Development and Heritage: Traditional Food and Cuisine as Tourist Attractions in Rural Areas". Sociologia Ruralis, 38/1, 21-34.

Creswell, J. W. (2007). “Qualitative Inquiry \& Research Design: Choosing Among Five Approaches”. Sage: California.

Çolak, O. (2009). Turistik Ürün Çeşitlendirme Kapsamında Kırsal Turizm ve Kırsal Turizm Işsletmeciliği: Sirince Örneği. Yayınlanmamış Yüksek Lisans Tezi. Adnan Menderes Üniversitesi SBE Turizm ABD.

Ergur, Ali. (2012). "Hermetik Yaşam Döngüsünün Kuruluşu: Sanayi-Sonrası Yaşam Biçimleri, Tüketim Örüntüleri ve Kentle Steril Temas Yordamları”. Galatarasay Üniversitesi İletişim Fakültesi Yayını, Özel Sayı, 2, 11-67.

Fennell, D. (2007). Ecotourism. New York: Routledge.

Fiske, J. (2012). Popüler Kültürü Anlamak. Çev.: Süleyman Irvan. İstanbul: Parşömen Yayınları.

Garipağaoğlu, N. (2010). "Türkiye'de Kentleşmenin, Kent Sayısı, Kentli Nüfus Kriterlerine Göre İncelenmesi ve Coğrafi Dağılışı”. Marmara Coğrafya Dergisi, Temmuz, 22, 1-42.

George, E. W., Mailr, H., \& Reid, D. G. (2009). Rural Tourism Development: Localism and Cultural Change. UK: Channel View Publication.

Giddens, A. (2000). Sosyoloji. Ankara: Ayraç Yayınevi.

Greffe, X. (1994). "Is Rural Tourism a Lever for Economic and Social Development?”. Journal of Sustainable Tourism, 2, 23-40.

Hall, C. M. (2008). "Sustainable Rural Area Tourism: Development and Issues". EDS National Conference, June 11-12, Auckland.

Hatipoğlu, A. etc. (2013). "Yöresel Yemeklerin, Kırsal Turizm İşletmeleri Mönülerinde Kullanım Düzeyleri: Gelveri Örneği”. Uluslararast Sosyal ve Ekonomik Bilimler Dergisi, 3/1, 6-11.

Işık, İ. E. (2009). Mekân ve Toplum. Eds. Iş̧ı, İ., E., \& Şentürk, Y. Özneler, Durumlar ve Mekânlar. İstanbul: Bağlam Yayıncılık.

Karaküçük, S., \& Gürbüz, B. (2007). Kent(li)leşme. Ankara: Baran Ofset.

Kıray, M. B. (2005). Tüketim Normları Üzerine Karşılaştırmalı Bir Araştırma. İstanbul: Bağlam Yayıncılık. Maccannell, D., (2002). “The Ego Factor in Tourism”. Journal of Consumer Research, 29/1, 146-151. 
Munt, I., (1994). “Eco-tourism or ego-tourism?”. Race \& Class, Vol: 36, No:1, 49-60.

Özünel, E. Ö. (2011). "Kültür Turizminde Yöresel ve Otantik Olanı Sorgulamak ve Tüketilmiş Mekânları Yeniden Üretmek Üzerine”. Turkish Studies, 6/4, 255-262.

Silverman, D. (2005). Qualitative research. Ed. Sage: London.

Slattery, M. (2010). Sosyolojide Temel Fikirler. Bursa: Sentez Yayınc1lık.

Storey, D. (2006). "Images of Rurality: Commodification and Place Promotion". The Rural Citizen: Governance, Culture and Wellbeing in the $21^{\text {st }}$ Century Compilation. UK: University of Plymouth.

Tashakkori, A., \& Teddlie, C. (2003). Handbook of Mixed Methods in Social \& Behavioral Research. Sage: CA.

Turkan, I. (2012). “Alışveriş Tüketim Mabetleri: Sosyoekonomik Açıdan Mekân Tüketiminde Türkiye Örneği”. Galatarasay Üniversitesi Illetişim Fakültesi Yayını, Özel Sayı 2, 85-104.

Urry, J. (1995). Consuming Places. London: Routledge.

Urry, J. (1999). Mekânları Tüketmek. Çev.: R. G. Öğdül. İstanbul: Ayrıntı Yayınları.

Weaver, D. B. (2002). "The Evolving Concept of Ecotourism and Its Potential Impacts”. International Journal of Sustainable Development, 5/3, 251-264.

Yıldııı, A., \& Şimşek, H. (2011). Sosyal Bilimlerde Nitel Araştırma Yöntemleri. Ankara: Seçkin Yayıncılık.

Yılmaz, G. Ö., Gürol, N. K. (2012). "Balıkesir İlinin Kırsal Turizm Potansiyelinin Değerlendirilmesi”. KMÜ Sosyal ve Ekonomik Araştırmalar Dergisi, 14/23, 23-32.

\section{İnternet Kaynakları}

Antalya İl Kültür ve Turizm Müdürlüğü (2012), Dünden Bugüne Antalya Cilt:1, Antalya Valiliği İl Külttür ve Turizm Müdürlüğü Yayınları, 2. Bask1, Mayıs 2012, Kaynak: http://www.antalyakulturturizm. gov.tr/Eklenti/8861,dundenbuguneantalyaciltipdf.pdf?0 (Erişim Tarihi: 06.03.2014).

Uğurlu, Ö., \& Tire, E. (2011). "Postmodern Yaşamda İnsan- Doğa İlişkisi: Sanal Çiftlik 'Farmville' Örneği’. 13. International Culturel Studies Symposium Change and Challenge, Ege Üniversitesi, İzmir, 4-6 Mayıs 2011, Kaynak: http://ozgeugurlu.com/wp-content/uploads/2012/05/FV-son.doc (Erişim Tarihi: 21.02.2014).

www.fullantalya.com/gozleme-ve-nar-suyu-cumhuriyeti-cakirlar/ (Erişim Tarihi: 10.03.2014)

www.ktbyatirimisletmeler.gov.tr/TR,9854/sinir-giris-cikis-istatistikleri.html (Erişim Tarihi: 18.05.2014)

www.tuik.gov.tr/PreTablo.do?alt_id=1059 (Erişim Tarihi: 18.05.2014) 
